$\begin{array}{ll}\text { Volume } & : 05 \\ \text { Nomor } & : 02 \\ \text { Bulan } & : \text { Mei } \\ \text { Tahun } & : 2019 \\ \text { http } & : \text { //ejurnal.pps.ung.ac.id/index.php/AKSARA/index }\end{array}$

\title{
KEPEMIMPINAN KEPALA MADRASAH DAN MOTIVASI GURU TERHADAP KINERJA PENGAWAS
}

\author{
Lisnawaty Dukalang \\ Pengawas Madya KenKemenag Kota Gorontalo \\ lisnawatidukalang52@gmail.com
}

Received: 29 Februari 2019; Revised: 12 April 2019; Accepted: 15 April 2019

\begin{abstract}
Abstrak
Penelitian ini bertujuan untuk mengetahui dan menganalisis besarnya pengaruh kepemimpinan kepala madrasah dan motivasi guru terhadap kinerja pengawas di kota Gorontalo baik secara simultan maupun parsial. Metode analisis yang digunakan adalah regresi linier berganda. Teknik pengambilan sampel yang digunakan pada penelitian adalah purposive sample yaitu pengambilan subjek didasarkan atas adanya tujuan tertentu dan teknik pengumpulan data melalui kuisioner, observasi, wawancara. Hasil penelitian menunjukkan bahwa Variabel kepemimpinan madrasah (X1) berpengaruh signifikan terhadap variabel dependen kinerja pengawas (Y) dengan arah koefisien positif sebesar 0,298. Nilai tersebut bermakna setiap penambahan 1\% leadership function, maka kinerja karyawan meningkat sebesar 0,298 atau 29,80\%. Variabel motivasi guru (X2) berpengaruh signifikan terhadap variabel dependen Kinerja (Y) dengan arah koefisien positif sebesar 0,530 . Nilai tersebut bermakna setiap penambahan $1 \%$ motivasi guru, maka kinerja meningkat sebesar 0,530 atau $53,00 \%$. pengujian nilai $\mathrm{R}^{2}$ sebesar $0,586(58,60 \%)$ menunjukkan bahwa besarnya kontribusi variabel independen yang terdiri dari pengaruh kepemimpinan kepala madrasah dan motivasi guru terhadap kinerja pengawas di kota Gorontalo.
\end{abstract}

Kata kunci: leadership, motivasi, kinerja.

\section{PENDAHULUAN}

Sejalan dengan semakin meningkatnya tuntutan masyarakat terhadap akuntabilitas sekolah, maka meningkat pula tuntutan terhadap para kepala sekolah. Mereka diharapkan mampu melaksanakan fungsinya baik sebagai manajer dan leader. Untuk meningkatkan kemampuan kepala sekolah dan tenaga kependidikan yang lain, pemerintah Indonesia telah menunjukkan good will, dengan memperhatikan kesejahteraan melalui beberapa langkah antara lain: pemberian gaji, kewenangan, dan otonomi yang cukup untuk memperkuat peran manajerial mereka di sekolah. Dengan diterbitkannya instrumen kebijakan baru, maka para kepala sekolah akan segera mendapat kompensasi meningkat, dukungan profesional, dan otonomi. Kepemimpinan atau leadership adalah kemampuan seseorang untuk mempengaruhi orang lain agar bekerjasama sesuai dengan rencana demi tercapainya tujuan yang telah ditetapkan. Dengan demikian kepemimpinan memegang peranan penting dalam manajemen, bahkan kepemimpinan adalah inti dari manajemen.

Kepemimpinan berasal dari kata pimpin yang memuat dua hal pokok, yaitu pemimpin sebagai subjek dan yang dipimpin sebagai objek. Kata pimpin mengandung pengertian mengarahkan, membina, atau mengatur, dan menunjukan ataupun mempengaruhi. Pemimpin mempunyai tanggung jawab, baik secara fisik maupun spritual terhadap keberhasilan aktivitas kerja dari yang dipimpin. Seorang pemimpin yang efektif adalah seorang yang responsif artinya selalu tanggap terhadap setiap persoalan, kebutuhan, harapan, dan impian dari mereka yang dipimpinnya. Selain itu, pemimpin selalu aktif dan proaktif dalam mencari solusi dari setiap permasalahan ataupun tantangan yang dihadapi. Seorang pemimpin yang efektif adalah seorang pelatih atau pendamping bagi orang orang yang dipimpinnya (performance coach). Artinya pemimpin memiliki kemampuan untuk menginspirasi dan mendorong bawahannya dalam menyusun perencanaan (termasuk rencana kegiatan, target atau sasaran, rencana kebutuhan sumber daya dan sebagainya) melakukan kegiatan sehari hari seperti monitoring dan pengendalian, serta 


$\begin{array}{ll}\text { Volume } & : 05 \\ \text { Nomor } & : 02 \\ \text { Bulan } & : \text { Mei } \\ \text { Tahun } & : 2019 \\ \text { http } & : \text { //ejurnal.pps.ung.ac.id/index.php/AKSARA/index }\end{array}$

mengevaluasi kinerja dari bawahannya.

Robbins (2001: 155-156) mendefinisikan motivasi sebagai "the process that account for an individual's intensity, direction, and persistence of effort toward attaining a goal". Hal ini dipertegas oleh Suryana Sumantri (2001: 53) yang mengungkapkan bahwa motivasi adalah proses yang sangat penting untuk mengerti mengenai mengapa dan bagaimana perilaku seseorang dalam bekerja atau dalam melakukan suatu tugas tertentu. Oleh karena itu, untuk dapat mengarahkan perilaku produktif dan efisien, masalah motivasi ini perlu diketahui dan dikaji lebih dalam.

Dari beberapa uraian di atas, dapat dilihat bahwa motivasi itu memang sering dikaitkan dengan pengertian keinginan (wants, desire), tujuan (aims, goals), kebutuhan (needs), dorongan (drives), motif, dan insentif. Wallen \& Wallen (1978: 31) mengakui bahwa topik motivasi ini merupakan sesuatu yang sangat luas (immense). Pada dasarnya motivasi tersebut melibatkan kebutuhan yang terdapat pada individu dan insentif atau tujuan yang harus ditemukan di luar individu.

Apabila ditelusuri lebih dalam, istilah motivasi itu sendiri merupakan turunan dari kata 'motive' yang berasal dari bahasa Latin 'movere' yang berarti to move 'bergerak'. Istilah ini, menurut Suryana Sumantri (2001: 53), biasanya digunakan untuk menunjukkan suatu pengertian yang melibatkan tiga komponen utama, yaitu (1) pemberi daya pada perilaku manusia (energizing); (2) pemberi arah pada perilaku manusia (directing); (3) bagaimana perilaku itu dipertahankan (sustaining).

Jadi, pada dasarnya perilaku diarahkan pada suatu tujuan dalam rangka memenuhi kebutuhan individu. Proses motivasi sebagai pengarah perilaku dapat dikatakan sebagai suatu siklus dan merupakan suatu sistem yang terdiri dari tiga elemen (Suryana Sumantri, 2001: 54). Ketiga elemen tersebut adalah: kebutuhan (needs), dorongan (drives), dan tujuan (goals). Ketiga elemen itu saling mendukung dan saling mempengaruhi.

Suatu tujuan dari siklus motivasi adalah segala sesuatu yang akan meredakan suatu kebutuhan dan akan mengurangi dorongan. Jadi pencapaian suatu tujuan cenderung akan memulihkan ketidakseimbangan menjadi keseimbangan yang bersifat fisiologis dan psikologis.

Peningkatan kinerja karyawan di lingkungan Kementerian Agama oleh pemimpin tidak lain adalah untuk meningkatkan tugas dan fungsinya sebagai seorang karyawan. Secara umum konsep kinerja pada dasarnya dapat dilihat dari dua segi yaitu kinerja karyawan (per individu) dan kinerja organisasi. Kinerja karyawan adalah hasil kerja perseorangan dalam suatu organisasi sedangkan kinerja organisasi adalah totalitas hasil kerja yang di capai suatu organisasi. Kinerja karyawan dan kinerja organisasi memiliki keterkaitan yang sangat erat. Tercapainya tujuan organisasi tidak bisa dilepaskan dari sumber daya yang dimiliki oleh organisasi yang digerakkan atau dijalankan karyawan yang berperan aktif sebagai pelaku dalam upaya pencapaian tujuan organisasi tersebut.

Sinambela, dkk (2011:136), mengemukakan bahwa kinerja karyawan didefinisikan sebagai kemampuan karyawan dalam melakukan sesuatu keahlian tertentu. Kinerja karyawan sangatlah perlu, sebab dengan kinerja ini akan diketahui seberapa jauh kemampuan karyawan dalam melaksanakan tugas yang dibebankan kepadanya. Untuk itu diperlukan penentuan kinerja yang jelas dan terukur serta ditetapkan secara bersama-sama yang dijadikan sebagai acuan.

Kinerja individu didefinisikan sebagai kemampuan individu dalam melakukan sesuatu dengan keahlian tertentu. Senada dengan pendapat tersebut, Stephen Robbins mengemukakan bahwa kinerja diartikan sebagai hasil evaluasi terhadap pekerjaan yang dilakukan individu dibandingkan dengan kriteria yang telah ditetapkan bersama (Robbins, 1996:439). Kedua konsep di atas menunjukkan bahwa kinerja seseorang sangatlah perlu, sebab dengan kinerja akan diketahui seberapa jauh kemampuan seseorang dalam melaksanakan tugasnya. Untuk mengetahui hal itu diperlukan penentuan kriteria pencapaiannya yang ditetapkan secara bersama-sama.

82 AKSARA Jurnal Ilmu Pendidikan Nonformal 


$\begin{array}{ll}\text { Volume } & : 05 \\ \text { Nomor } & : 02 \\ \text { Bulan } & : \text { Mei } \\ \text { Tahun } & : 2019 \\ \text { http } & : \text { //ejurnal.pps.ung.ac.id/index.php/AKSARA/index }\end{array}$

\section{KAJIAN TEORI Kinerja}

Kinerja yang baik akan dipengaruhi oleh dua hal yaitu kemampuan dan motivasi kerja yang baik (Mitchell, 1978:152) dalam Sinambela (2012:9), kemampuan seseorang dipengaruhi oleh pemahamannya atas jenis pekerjaan dan keterampilan melakukannya, oleh karenanya seseorang harus dapat meningkatkan kemampuan dan keterampilannya. Selain itu kontribusi motivasi kerja terhadap kinerja tidaklah dapat diabaikan. Meskipun kemampuan pegawai sangat baik apabila otivasi kerjanya rendah, sudah barang tentu kinerjanya juga akan rendah. Dengan demikian Mitchell memformulasikan kinerja adalah fungsi dari kemampuan dikali motivasi.

Tercapainya atau tidaknya tujuan organisasi akan ditentukan oleh sejauhmana pemahaman dan penerimaan karyawan tentang tujuan organisasi. Yang dimaksud dengan tujuan organisasi adalah suatu target yang hendak dicapai oleh organisasi untuk kurun waktu tertentu. Tujuan haruslah dirumuskan dengan jelas sehingga tidak membingungkan karyawan dalam pencapaiannya. Masing-masing karyawan yang memasuki saatu organisasi pasti mempunyai tujuan yang berbeda-beda, perbedaan tersebut haruslah dipahami dan dikelola oleh pimpinan untuk pencapaian tujuan organisasi. Pegawai akan termotivasi untuk mencapai tujuan organisasi jika dia menyakini bahwa dengan tercapaianya tujuan organisasi tersebut tujuannyapun akan tercapai pula.

\section{Fungsi Kepemimpinan}

Menurut Kadji (2008), Leadership atau kepemimpinan merupakan energi dinamis bagi sumber-sumber dan alat-alat, serta manusia dalam suatu organisasi. Demikian pentingnya peran kepemimpinan dalam suatu usaha pencapaian tujuan organisasi, sehingga dapat dikatakan bahwa sukses atau gagalnya yang dialami oleh suatu organisasi dalam perspektif implementasi kebijakan publik, sebagian besar ditentukan oleh kualitas kepemimpinan yang dimiliki oleh orang-orang yang diserahi tugas memimpin dalam organisasi publik itu. Seorang pemimpin yang baik memusatkan perhatian pada apakah dia (memiliki keyakinan dan karakter yang handal), apa yang diketahuinya (pekerjaan, tugas dan sifat manusia), dan apa yang dilakukannya (melaksanakan, memotivasi, dan memberi arah) serta apa yang dikoordinasikannya dalam implementasi sebuah kebijakan, organisasi publik.

Dalam tataran ini, dapat ditekankan bahwa seorang pemimpin yang baik adalah seorang yang tidak saja melaksanakan sendiri tindakan-tindakan yang bersifat strategis, akan tetapi seorang pemimpin yang baik khususnya dalam perspektif implementasi kebijakan publik, paling tidak harus mampu mengejawentahkan (mewujudkan, melaksanakan) empat fungsi kepemimpinan (Leadership function), yang dideskripsikan berikut ini:

\section{- Pemimpin Sebagai Koordinator}

Kadji (2008), Seorang leader dapat pula disebut sebagai koordinator yang dapat menjalankan tugastugas koordinasi dalam manajemen implementasi kebijakan publik.

Koordinasi (K) dalam setiap aktivitas organisasi publik, hanya akan terwujud jika seorang leader mampu menciptakan harmonisasi $(\mathrm{H})$, artinya terkondisikan suatu suasana yang aman dan damai dalam kesahajaan yang jauh dari rasa mencekam akibat power otokrasi dan arogansi manajeriar seorang leader. Berikut seorang leader harus mampu menumbuhkan semangat keselarasan (S) antar intern staf dan pimpinan dalam organisisi, juga menjaga tidak terjadinya tumpang tindih program dan kebijakan organisasi yang dipimpinnya, sebagai wujud sinkronisasi (keselarasan). Selanjutnya seorang leader harus mampu menyatu-padukan dalam ketulusan (I) yang bermakna diantara para staf dan pimpinan organisasi, sehingga apa yang menjadi visi dan misi organisasi akan tercapai dalam sebuah realitas yang konkrit dan terarah. 


$\begin{array}{ll}\text { Volume } & : 05 \\ \text { Nomor } & : 02 \\ \text { Bulan } & : \text { Mei } \\ \text { Tahun } & : 2019 \\ \text { http } & : \text { //ejurnal.pps.ung.ac.id/index.php/AKSARA/index }\end{array}$

Tegasnya, koordinasi (K) yang baik akan tercapai secara komprehensif, jika terciptautuhkan kondisi harmonisasi $(\mathrm{H})$, terjadi sinkronisasi (S), dan kehandalan integrasi (I) kebijakan program dengan dukungan sumber daya manusia serta fasilitas yang memadai untuk kepentingan publik dalam perspektif manajemen implementasi kebijakan publik. Maka, formula $\mathrm{K}=\mathrm{H}+\mathrm{S}+\mathrm{I}$, akan menjadi tawaran kontemporer penulis dalam melihat eksistensi pemimpin dan kepemimpinan dalam perspektif implementasi kebijakan publik.

Sebagai fasilitator, seorang pemimpin tidak hanya menyampaikan informasi kepada implementor kebijakan, akan tetapi harus menjadi fasilitator yang mengedepankan prinsip "to facilitate of working" (memberi kemudahan dalam bekerja) kepada para impelementor kebijakan, agar mereka dapat bekerja dalam suasana yang menyenangkan, gembira, penuh semangat, tidak cemas, dan berani mengemukakan pendapat secara terbuka, sebagai modal dasar bagi para implementor untuk berkembang dan siap beradaptasi, menghadapi berbagai kemungkinan dan tantangan.

Dengan demikian seorang pemimpin dalam meng-implementasikan sebuah kebijakan publik, seharusnya memiliki dan menerapkan hal-hal berikut ini: a) tidak berlebihan mempertahankan pendapat dan keyakinan, atau kurang terbuka, b) dapat lebih mendengarkan para implementor kebijakan, terutama tentang aspirasi dan perasaannya, c) mau dan mampu menerima ide para implementor yang inovatif, dan kreatif, bahkan sesulit sekalipun, d) lebih meningkatkan perhatiannya terhadap hubungan dengan implementor kebijakan, e) dapat menerima feedback, baik yang sifatnya positif maupun negatif, dan menerimanya sebagai pandangan yang konstruktif demi pengembangan peran organisasi yang dipimpinnya, f) toleransi terhadap kesalahan yang diperbuat oleh implementor kebijakan selama kesalahan itu masih dapat diperbaiki untuk kepentingan suksesnya pelaksanaan sebuah kebijakan publik, dan g) menghargai prestasi dan kinerja implementor kebijakan sebagai upaya peningkatan produktivitas organisasi.

Sebagai seorang motivator, maka pemimpin harus mampu mengarahkan dan mendorong perilaku atau keinginan para implementor dalam melaksanakan setiap kebijakan organisasi. Dalam dimensi inilah, seorang pemimpin dapat melakukan hal-hal seperti: i) memberikan penghargaan yang patut kepada implementor yang memiliki kinerja dan prestasi yang baik, ii) sebaliknya konsisten juga dalam menerapkan sanksi kepada implementor yang lalai dalam tugasnya, iii) sebagai seorang leader mampu memberi contoh teladan yang baik, agar bisa diikuti dan ditaati oleh implementor kebijakan karena memang antara sikap, perilaku, dan tindakan seorang pemimpin harus seiring sejalan satu kata dalam aksi.

Sebagai motivator dalam perspektif implementasi kebijakan, maka seorang pemimpin harus mampu membangkitkan semangat dan motivasi kerja para implementor kebijakan, sehingga menyebabkan terjadinya suatu perubahan energi yang ada pada diri para implementor, baik menyangkut kejiwaan, perasaan, maupun emosi, dan kemudian bertindak atau melaksanakan sesuatu pekerjaan dalam kerangka mencapai tujuan yang ditetapkan. Relevansinva dengan itulah, maka seorang pemimpin dipandang sebagai motivator yang handal ketika memperhatikan prinsipprinsip, antara lain: a) bahwa para implementor akan bekerja keras jika memiliki minat dan perhatian terhadap tugas dan pekerjaannya, b) memberikan job description yang jelas dan dapat dimengerti oleh para implementor, c) memberikan penghargaan terhadap hasil kerja dan prestasi para implementor, dan d) memberikan penilaian terhadap kinerja para implementor secara tranparan, berkeadilan dan dapat dipertanggung-jawabkan.

Kadji (2008), Dalam dimensi ini proses kepemimpinan bermuara eksistensi seorang pemimpin yang memiliki kemauan dan kemampuan untuk berubah, memiliki suatu sikap yang dinamis dan tidak statis. Hal ini diperlukan karena pada kenyataannya semua berubah, dan yang tidak berubah itu adalah perubahan itu sendiri. Karena itulah, seorang pemimpin dalam melaksanakan tugas-tugas 


$\begin{array}{ll}\text { Volume } & : 05 \\ \text { Nomor } & : 02 \\ \text { Bulan } & : \text { Mei } \\ \text { Tahun } & : 2019 \\ \text { http } & : \text { //ejurnal.pps.ung.ac.id/index.php/AKSARA/index }\end{array}$

kepemimpinannya, maka seorang pemimpin harus dapat mendinamisir dalam menciptakan suasana kondusif yang menyenangkan bagi semua staf ataupun implementor kebijakan oleh Fiedler bahwa "in the very favorable conditions in which the leader has power, informal backing, and a relatively wellstructured, task, the grouf is ready to directed, and the grouf expects to be told what to do".

Kondisi dinamis merupakan suatu situasi yang kondusif dan menyenangkan dimana pemimpin dapat diterima oleh para implemenior kebijakan, sebaliknya pemimpin juga mampu melihat dan menerima perbedaan kompetensi dari para implementor untuk dibimbing menjadi sebuah kekuatan organisasi dalam rangka mengimplementasikan tugas-tugas dan kebijakan organisasi yang dipimpinnya. Tegasnya, seorang pemimpin mampu mendinamisir suatu iklim yang aman bagi semua implementor dalam melaksanakan kegiatan sesuai bidang tugasnya masingmasing.

Kepemimpinan adalah suatu proses yang kompleks dimana seorang leader mampu mempengaruhi implementor kebijakan untuk mencapai suatu visi, misi, tugas, atau sasaran dan mengarahkan para implementor dengan cara membuat kondisi organisasi lebih kohesif. Wirjana (2005:11) dalam Kadji (2008:70-71), mengemukakan kepemimpinan akan efektif bila: "pemimpin dapat memberi inspirasi, memberi dukungan dan memotifasi kepada yang dipimpinnya untuk bekerja sama, bertindak mencapai tujuan organisasi dan didalam melakukan hal itu yang dipimpin akan mengalami proses pengembangan kepemimpinan, sehingga kelak meskipun akan dapat menjadi pemimpin".

Sebagai seorang motivator, maka pemimpin harus mengarahkan dan mendorong perilaku atau keinginan para implementor dalam melaksanakan setiap kebijakan organisasi. Dalam dimensi inilah, seorang pemimpin dapat melakukan hal-hal seperti: i) memberikan penghargaan yang patut kepada implementor yang memiliki kinerja dan prestasi yang baik, ii) sebaliknya konsisten juga dalam menerapkan sanksi kepada implementor yang lalai dalam tugasnya, iii) sebagai seorang leader mampu memberikan contoh teladan yang baik, agar bisa diikuti dan ditaati oleh implementor kebijakan, karena memang antara sikap, perilaku, dan tindakan seorang pemimpin harus seiring sejalan, satu kata dalam aksi.

Sebagai motivator dalam perspektir kebijakan, maka seorang pemimpin harus mampu membangkitkan semangat dan motivasi kerja para implementor kebijakan, sehingga menyebabkan terjadinya suatu perubahan energy yang ada pada diri implementor, baik menyangkut kejiwaan, perasaan, maupun emosi, dan kemudian bertindak atau melaksanakan sesuatu pekerjaan dalam kerangka mencapai tujuan yang ditetapkan. Relevansinya dengan itulah, maka seorang pemimpin dipandang sebagai motivator yang handal ketika memperhatikan prinsip-prinsip, antara lain: a) bahwa para implementor akan bekerja keras jika memiliki minat dan perhatian terhadap tugas dan pekerjaannya, b) memberikan job description yang jelas dan penghargaan terhadap hasil kerja dan prestasi para implementor, dan d) memberikan penilaian terhadap kinerja para implementor secara transparan, berkeadilan dan dapat dipertanggungjawabkan.

Fungsi budaya pada umumnya sukar dibedakan dengan fungsi budaya kelompok atau budaya organisasi, karena budaya merupakan gejala social. Menurut Ndraha (1997:21) ada beberapa fungsi budaya, yaitu: a) sebagai identitas dan citra suatu masyarakat, b) sebagai pengikat suatu masyarakat, c) sebagai sumber, d) sebagai kekuatan penggerak, e) sebagai kemampuan untuk membentuk nilai tambah, f) sebagai pola perilaku, g) sebagai warisan, h) sebagai pengganti formalisasi, i) sebagai mekanisme adaptasi terhadap perubahan, $\mathrm{j}$ ) sebagai proses yang menjadikan bangsa kongruen dengan Negara sehingga terbentuk nation-state.

Berbagai literatur mendefinisikan bahwa organisasi dengan berbagai versi Steephen P. Robbins misalnya mengatakan "bahwa budaya organisasi mengacu ke sistem makna bersama yang dibentuk oleh anggota-anggotanya sekaligus pembeda organisasi itu dengan organisasi-organisasi 


$\begin{array}{ll}\text { Volume } & : 05 \\ \text { Nomor } & : 02 \\ \text { Bulan } & : \text { Mei } \\ \text { Tahun } & : 2019 \\ \text { http } & : \text { //ejurnal.pps.ung.ac.id/index.php/AKSARA/index }\end{array}$

lain. Sistem pemaknaan bersama sama tersebut, merupakan seperangkat karakteristik utama nilainilai organisasi tersebut (a sistem pf shared meaning held by members that distinguishes the organization from other organization. This sistem of shared meaning is, on closer examination, a set of key characteristic that the organization values) oleh Robbins (2006) kemudian karakteristik tersebut dibagi tujuh (7) macam seperti : 1) Inovasi dan keberanian mengambil resiko, 2) Perhatian terhadap detail, 3) Orientasi hasil, 4) Orientasi orang, 5) Orientasi tim, 6) Keagresif, dan 7) Kemantapan

\section{Motivasi}

Motivasi berprestasi merupakan keinginan untuk menyelesaikan sesuatu, untuk mencapai suatu standar kesuksesan, dan untuk melakukan suatu usaha dengan tujuan untuk mencapai kesuksesan (Santrock, 2003: 474). Individu yang memiliki motivasi berprestasi memiliki harapan untuk sukses yang lebih besar daripada ketakutan akan kegagalan, lebih memilih resiko tugas yang sedang, dan tekun usahanya ketika menghadapi tugas yang semakin sulit.

Menurut Thoha (2002: 208-209) ada beberapa karakteristik dari orang-orang memiliki motivasi berprestasi tinggi, antara lain: 1) kesiapan menghadapi resiko, 2) memerlukan umpan balik yang segera, 3) memperhitungkan keberhasilan, dan 4) menyatu dengan tugas. Sementara itu orang tidak memiliki motivasi berprestasi, memiliki tiga ciri-ciri khusu sebagai berikut: 1) mengabaikan kesuksesan tugas karena cenderug meragukan kemampuan yang dimiliki atau menganggap kesuksesan tergantung pada faktor lain di luar pengetahuannya, 2) putus asa ketika mengahadpi kesulitan karena percaya bahwa kegagalan berkaitan erat dengan ketidakmampuan dalam mengerjakan sesuatu, 3) semangat kerjanya rendah karena beranggapan bahwa hasil kerja tidak ada hubungan dengan usaha kerja keras.

\section{Metode dan disain Penelitin}

Dalam penelitian ini peneliti menggunakan jenis penelitian kuantitatif dengan menggunakan metode "survey". Sebagaimana dikemukakan oleh Sugiyono (2008:8) bahwa penelitian kuantitatif adalah metode penelitian yang berlandaskan pada filsafat positivisme, digunakan untuk meneliti pada populasi atau sampel tertentu, pengumpulan data menggunakan instrumen penelitian, analisis data bersifat kuantitatif/statistik, dengan tujuan untuk menguji hipotesis yang teah ditetapkan.

Sejalan dengan Effendi (Riduwan, 2009: 65) mengatakan bahwa penelitian survey adalah penelitian yang mengambil sampel dari suatu populasi dan menggunakan kuisioner sebagai alat pengumpulan data yang pokok. Dalam penelitian ini variabel yang dimaksud adalah fungsi kepemimpinan dan kinerja karyawan. Dalam penelitian kuantitatif ini, penentuan jumlah informan yang akan digunakan bukan pada kuantitasnya, namun berdasarkan kualitas informasi yang diberikan atas seluruh pernyataan yang ada dalam penelitian.

\section{Hasil penelitian dan Pembahasan \\ Pembahasan}

Koefisien determinasi digunakan untuk menguji ketepatan dari model regresi, yaitu besarnya pengaruh variabel independen terhadap variabel dependen. Berdasarkan tabel di bawah dapat dilihat bahwa nilai $\mathrm{R}^{2}$ adalah sebesar 0,586 atau 58,60\%. Hasil ini menunjukkan bahwa besarnya kontribusi variabel independen secara bersama-sama (simultan) yang terdiri dari Leadership function dan budaya organisasi yang dapat disumbangkan untuk perubahan variasi variabel terikat kinerja karyawan sebesar 0.586 atau $58,60 \%$, sedangkan sisanya sebesar 0,414 atau $41,40 \%$ dipengaruhi oleh variabel lain di luar model. 


$\begin{array}{ll}\text { Volume } & : 05 \\ \text { Nomor } & : 02 \\ \text { Bulan } & : \text { Mei } \\ \text { Tahun } & : 2019 \\ \text { http } & : \text { //ejurnal.pps.ung.ac.id/index.php/AKSARA/index }\end{array}$

Kepemimpinan kepala madrasah (X1) berdasarkan tabel di atas menunjukkan nilai sig 0,048 (4,8\%). Hasil tersebut jika dibandingkan dengan nilai $\alpha$ yang digunakan yaitu sebesar 5\% masih lebih kecil sehingga variabel kepemimpinan kepala madrasah $(X 1)$ adalah berpengaruh signifikan (nilai sig < dari nilai a 5\%). Dengan demikian hipotesis secara parsial kepemimpinan kepala madrasah berpengaruh terhadap kinerja pengawas, diterima.

Variabel motivasi guru berdasarkan tabel di atas menunjukkan nilai sig $0,001(0,1 \%)$. Hasil tersebut jika dibandingkan dengan nilai $\alpha$ sebesar 5\% masih lebih kecil sehingga variabel motivasi guru (X2) adalah berpengaruh signifikan (nilai sig $<$ dari nilai $\alpha 5 \%$ ). Dengan demikian hipotesis secara parsial motivasi guru berpengaruh terhadap kinerja pengawas, diterima.

Berdasarkan hasil analisis data dan pengujian hipotesis pengaruh variabel kepemimpinan kepala madrasah (X1), dan motivasi guru terhadap kinerja pengawas (Y) dapat dijelaskan dalam model persamaan sebagai berikut:

\section{$Y=2,804+0,298 X_{1}+0,530 X_{2}+0,414 \varepsilon$ dengan $R^{2}=0,586$}

Berdasarkan model persamaan tersebut, maka dapat dijelaskan sebagai berikut:

1. Angka konstan dari Unstandardized Coefficient yang dalam penelitian ini adalah sebesar 2,804. Angka ini memiliki makna jika tidak ada penambahan kepemimpinan kepala madrasah dan motivasi, maka jumlah kinerja akan sebesar 2,804.

2. Variabel kepemimpinan kepala madrasah (X1) berpengaruh signifikan terhadap variabel dependen Kinerja (Y) dengan arah koefisien positif sebesar 0,298. Nilai tersebut bermakna setiap penambahan $1 \%$ kepemimpinan kepala madrasah, maka kinerja meningkat sebesar 0,298 atau $29,80 \%$

3. Variabel Motivasi Guru (X2) berpengaruh signifikan terhadap variabel dependen Kinerja (Y) dengan arah koefisien positif sebesar 0,530. Nilai tersebut bermakna setiap penambahan $1 \%$ budaya organisasi, maka kinerja meningkat sebesar 0,530 atau 53,00\%.

4. Nilai $\mathrm{R}^{2}$ sebesar $0,586(58,60 \%)$ menunjukkan bahwa besarnya kontribusi variabel independen yang terdiri dari kepemimpinan dan motivasi terhadap kinerja pengawas.

5. Nilai error term sebesar $100 \%-58,60 \%=41,40 \%$ atau 0,414 menunjukkan besarnya pengaruh variabel lain diluar model yang turut mempengaruhi variabel utama kinerja pengawas.

\section{Pembahasan}

Hasil pengujian secara parsial menunjukkan bahwa kepemimpinan kepala madrasah berpengaruh terhadap kinerja pengawas dengan arah koefisien positif sebesar 0,298 (29,80\%). Nilai tersebut bermakna setiap penambahan $1 \%$ kepemimpinan kepala madrasah, maka kinerja akan meningkat sebesar 0,298 (29,80\%). Berdasarkan hasil tersebut maka hipotesis kedua yang menyatakan "kepemimpinan kepala madrasah (X1) secara parsial berpengaruh terhadap kinerja" diterima.

Berdasarkan hasil penelitian dapat dijelaskan bahwa kepemimpinan kepala madrasah yang diterapkan, pada dasarnya masih harus lebih ditingkatkan lagi untuk menekan tingkat kinerja. Hal ini tercermin dari hasil penelitian yang mengungkapkan bahwa sebagian besar rata-rata responden sangat positif dalam memberikan jawaban terhadap penyataan yang diberikan. Kepemimpinan kepala madrasah yang dibangun merupakan suatu proses dalam organisasi yang melibatkan para pimpinan dalam menentukan kebijakan pimpinan yang menjadi tanggungjawab mereka. Kepemimpinan kepala madrasah memiliki arti penting dalam menjalankan organisasi untuk dapat mengkoordinator, memotivator, memfasilitator dan mendinamisator agar tercapai suatu tujuan organisasi yang lebih baik.

Kontribusi variabel kepemimpinan kepala madrasah menunjukkan pengaruh signifikan terhadap kinerja sebesar $29,8 \%$. Sedangkan variabel motivasi berpengaruh signifikan terhadap kinerja pengawas dengan arah koefisien positif sebesar 53,00\%. 


$\begin{array}{ll}\text { Volume } & : 05 \\ \text { Nomor } & : 02 \\ \text { Bulan } & : \text { Mei } \\ \text { Tahun } & : 2019 \\ \text { http } & : \text { //ejurnal.pps.ung.ac.id/index.php/AKSARA/index }\end{array}$

\section{Penutup}

Berdasarkan hasil analisis data yang dilakukan terhadap 40 responden maka dapat ditarik kesimpulan sebagai berikut: a) Variabel kepemimpinan kepala madrasah (X1) berpengaruh signifikan terhadap variabel dependen Kinerja (Y) dengan arah koefisien positif sebesar 0,298. Nilai tersebut bermakna setiap penambahan $1 \%$ kepemimpinan kepala madrasah, maka kinerja meningkat sebesar 0,298 atau 29,80\%. b) Variabel Motivasi guru (X2) berpengaruh signifikan terhadap variabel dependen Kinerja Pengawas (Y) dengan arah koefisien positif sebesar 0,530. Nilai tersebut bermakna setiap penambahan 1\% Motivasi Guru , maka kinerja Pengawas meningkat sebesar 0,530 atau 53,00\%. c) kepemimpinan kepala madrasah dan motivasi guru berpengaruh signifikan terhadap variabel dependen kinerja pengawas.

\section{Daftar Pustaka}

Arikunto Suharsimi. 2013. "Prosedur Penelitian, Suatu Pendekatan Praktik", Jakarta. Penerbit Rineke Cipta.

Budiharjo M. 2015. "Panduan Praktis Penilaian Kinerja Karyawan”, Jakarta. Penerbit Raih Asa Sukses.

Dewangga Aryadhuta Wisnu dkk. 2013. "Pengaruh Gaya Kepemimpinan Rektor Terhadap Kinerja Pegawai Non-Edukatif Pada Universitas Negeri Surabaya (Studi Pada Pegawai Di Kantor Pusat UNESA)", Jurnal Ilmu Administrasi Negara ISSN: 2354-600X, volume 1 Nomor 2 Tahun 2013, http://ejournal.unesa.ac.id/jurnal/publika/volume/280/vol1-nomer-2-2013, diakses tanggal 1 Mei 2015 pukul 10:00

Fadli Uus Md, dkk. 2012. "Pengaruh Kepemimpinan Dekan Terhadap Kepuasan Kerja Dosen (Studi Pada Dosen di Universitas Singaperbangsa Karawang)”, Jurnal Manajemen volume 10 Nomor 1 Oktober Tahun 2012, http://jurnal.feunsika.ac.id/wpcontent/uploads/2013/05/PEN GARUH-KEPEMIMPINAN-DEKAN-TERHADAPKPUASAN-KER JA-DOSEN.pdf, diakses tanggal 1 Mei 2015 pukul 10:15

Santrock, J.W. (2008). Psikologi Pendidikan (Edisi Kedua). Jakarta: Kencana. Santrock, Jhon. 2003. Adolescence (Perkembangan Remaja). Jakarta: Erlangga.

Supriyatna, Mamat. 2011. Bimbingan dan Konseling Berbasis Kompetensi Orientasi Dasar Pengembangan Profesi Konselor. Jakarta: Rajawali Press.

Thoha, Miftah. 2002. Perilaku Organisasi Konsep Dasar dan Aplikasi. Jakarta: PT. Raja Grafindo. 